\title{
Imagining theological education for Accra as a globalising city
}

\section{David Nii Anum Kpobi ${ }^{1}$}

\begin{abstract}
Increasing migration and its attendant repercussions have gradually created many unfavourable conditions in the city of Accra. The situation poses big challenges to both the local and national development agenda. Religious institutions, including the Church - which occupy an important place in the lives of Accra residents - have roles to play. This study proposes as one of the most effective approaches to the current situation, for theological institutions to overhaul and revise their educational strategies and goals. This is possible through a properly designed and regulated training scheme that gives adequate orientation and guidance to both faculty and students of theological institutions in Accra. Only through a conscious rethinking, reimagining and restructuring of existing training programmes and approaches can new attitudes and actions be expected, in relation to the social fractures in the city. The study adopts a qualitative approach with a multi-disciplinary and multi perspective thrust.
\end{abstract}

Key Words: Theological education, Accra, Globalising city, Urban mission

\section{Introduction}

This study is focussed on the capital city of Ghana, Accra, as a globalising city experiencing and manifesting the positive as well as negative effects of modern urban existence. After describing the processes undertaken and the challenges encountered, the findings, discoveries, surprises and other relevant issues arising from the research are presented and discussed. The main sections of the study include a description of the city of Accra giving indications about significant developments affecting its wellbeing, sustenance and flourishing with references to historical, socio-cultural, political, religious and related factors over many years. We also refer to various projections regarding where the city is heading in the next thirty years (i.e., by the year 2050). Subsequent sections are devoted to proposals for responding to the issues raised, including suggestions for a general overhaul of the curriculum for theological education and formation in Ghana.

David Nii Anum Kpobi is an Associate Professor of Missiology and Church History. He can be contacted atdnakpobi@gmail.com or dna.kpobi@trinity.edu,gh 


\section{A Brief History of the City of Accra}

The city of Accra is located within the Greater Accra Region, which is the smallest of the sixteen administrative regions of Ghana in terms of land size, and occupying a total land surface of 3,245 square kilometres ( 1.4 per cent) of the total land area of Ghana. In 2010, when the last official census was conducted, the population of $4,010,054$ made the Greater Accra region the second most populous after the Ashanti Region, accounting for 15.4 per cent of Ghana's total population. (GSS, 2010:53).

The arrival of European traders on the Gold Coast (now Ghana) beginning in the 15th century was the beginning of a new era on the west coast of Africa. In a matter of years, economic activities and new trading partnerships emerged between Europe and the Gold Coast which soon created a string of trading posts along the coast, mainly in Elmina, Cape Coast and Accra. The dynamics of the European coastal trade signaled the beginning of a redistribution of the spatial arrangements on the Gold Coast. It was also the first phase of an urbanising trend where the coastal towns became conditioned for greater economic development as a result of their better integration with European trade (Fage, 1969:52-55). The ensuing colonisation arrangements between the Dutch and English on the one hand and the indigenous African towns on the other, eventually created the "colonial city" which developed as a centre of commerce and administration rather than as a result of increasing industrial development. The consequence was the growth of urban centres of which Cape Coast and Accra would become the most prominent and dominant. (Fage, 1969:59).

In 1877, the British Colonial Government in the Gold Coast colony moved the capital from Cape Coast to Accra and enacted a law to acquire more land for the new seat of government. Two main reasons accounted for this move, namely the drier and less humid weather of Accra and its more conducive environment for the development of the livestock industry, a key component of the economy at the time. A Town Council was set up in Accra with powers for the provision of infrastructure to ensure orderly planning of the town, controlling the siting and quality of buildings and the layout of streets, among other things. Its specific responsibilities also included issues of environmental sanitation and managing the growth of the city (Quarcoopome, 1992:17). The development of the city progressed somehow steadily in spite of many ups and downs and in 1919, the new governor, Gordon Guggisberg, introduced more progressive measures which raised the status of Accra considerably.

The new status of Accra started to attract people from far and near who sought to benefit from the growing and buoyant commercial opportunities, introducing pressure on the city's inadequate resources. In response to this situation, the colonial administration enacted laws to ensure that sections of the city where Europeans 
lived were low-density and retained adequate sanitation, road systems, recreational facilities and security. This was in sharp contrast to the indigenous population who lived mostly in unplanned areas with poor infrastructure, sanitation and roads. (Grant \& Yankson, 2002:65). This unbalanced development trend continued even after Ghana gained political independence in 1957 and has not abated in spite of various efforts by succeeding governments. Migration from the rural areas of Ghana as well as the West African sub-region has continued to fuel various forms of stagnation in Accra leading to the current state where the population has completely outstripped the resources and capacities of the authorities and which continues to create unhealthy situations of tension and deprivation.

\section{Accra Today}

Today, the political administration of the Greater Accra Region is carried out through the local government system under which the region is divided into districts, each of which is administered by a Chief Executive, representing central government. The city of Accra is one of the two largest districts designated as Metropolitan Areas, the other being the port city of Tema.

\subsection{Population}

There are various indications of population censuses in Accra in the early part of the 20th century although no proper records exist to confer any legitimacy on the figures. The earliest recorded census we have sighted comes from a report of the Central Bureau of Statistics (GCO, 1973) which gives an indication that a census took place in the year $1948^{2}$. In 1950, however, the Central Bureau of Statistics published what was perhaps the first official population statistics of Accra which was recorded as 177,147 . Since then, national population statistics have been published every ten years. ${ }^{3}$ The next official census, scheduled for June 2020 , has been put on hold due to the onset of the corona virus pandemic.

\subsection{Population Estimates for the Next Decades}

In this study, we subscribe to the figures produced by the Ghana Statistical Service (GSS) which is the official government agency for compiling and analysing national

2 This reference, however, provides no figures and there are also indications that this was more of a de jure than a de facto count. In a de facto count, the exact date of the count is stated, i.e., the midnight of the date on which all persons were enumerated. A de jure count however may take place over many days or even months.

3 In 1980, no census was undertaken due to a military takeover the previous year which caused much disruption in governance and social life. A census was however duly undertaken in 1984 and again in 1990. 
statistics. The GSS makes the following projections for the population of Accra in the next thirty years:
2020 2,514,000 (Estimated national population: 31,072,940)
$2030 \quad 6,189,612$ (Estimated national population: 37,983,586)
$2050 \quad 8,700,125$ (Estimated national population: $\mathbf{5 2 , 5 0 3 , 7 2 1})^{4}$

Although population increases in many cities around the world, have often been fueled mainly by high fertility rates, migration appears to be the main factor in Accra and has been contributing to growing harsh socio-economic conditions as well as ethnic and linguistic diversity in the city. Besides other indicators, the population statistics of the 2010 census indicate that the indigenous Ga/Dangme population of Accra form a mere 27.4\% (GSS, 2010:62 Table 4.5), all others being migrants.

\subsection{Current State of the City}

Current economic and social projections are insistent that Accra will continue to suffer from inadequate infrastructure, increasing degradation of social norms and values and other forms of deprivation for at least the next two decades. For example, the report of the National Housing and Population Census (GSS, 2010:104) recorded that about $45 \%$ of Accra residents lived in some form of slum housing. These were areas that were overcrowded, had limited access to clean pipe-borne water and lived with poor sanitation facilities (Obeng-Odoom, 2011:355). Housing in Accra may be described as something of a paradox with a boom in supply for the wealthy, and scarcity for those at the lower ends of the income strata. According to Ghana Housing Profile (UN-HABITAT, 2011:22), 60\% of all urban households in Ghana occupied single rooms and many households in Accra were in facilities classified as improvised homes (i.e., kiosks, containers and similar structures). An additional two percent were living in uncompleted buildings and only $25 \%$ of households owned their houses (GSS, 2014:14). In the last six years, the situation of the homeless population has been growing from bad to worse and is unlikely to change for the better any time soon (GSS, 2014:108). In 2018, the unemployment rate in Ghana which was estimated at approximately $6.71 \%$ of the total labour force was above the worldwide unemployment rate. ${ }^{5}$

It is therefore clear that urbanisation in Accra is proceeding in the face of many unfavourable conditions and that unless some drastic measures are adopted to deal with these, Accra may be heading for a future of urban fractures and chaos

\footnotetext{
4 www.worldpopulationreview.co. See also Ghana Statistical Service, Population Projections \& Prospects, 2019, (Section 2.4.2) and https://www.macrotrends.net/cities/21107/accra/population 5 https://www.statista.com/statistics/279790/unemployment-rate-in-seclected-world-regions/
} 
in much of its day to day existence. (GSS, 2014:120). This calls for urgent and farreaching interventions to stem the tide and introduce prosperity much sooner than later and requiring careful formulation and implementation and the participation of all relevant stakeholders.

In this study, we make a case for including faith-based organisations in Accra in any attempts to deal with the numerous shortcomings in the city. Our main focus includes the contributions of theological institutions in adequately equipping students and others with relevant skills and tools for practising their vocation in urban centres. This research was therefore carried out within the framework of Christian ministry in an urban setting. The current general state of the city of Accra and the living conditions of many of its residents constitute a clear reproach to the fullness of life which the ministry of Jesus sought to promote for all humankind. In his ministry and utterances, Jesus displayed a positive bias and preferential option for the underprivileged and marginalised in society, and sought to alleviate their plight by getting the general society to overhaul its attitude to this category of individuals. This was based on the fundamental understanding that every human being is created in the image of God and deserves the enjoyment of basic needs. (UDHR, $1948)^{6}$. David Bosch has pointed out the systematic development of solidarity with the poor in Christian theology, particularly championed by the World Council of Churches since the 1960s. He explains why the expression "preferential option for the poor" should not be understood in exclusive terms as though God was interested only in the poor. In Bosch's words, "Once we recognise the identification of Jesus with the poor, we cannot any longer consider our own relation to the poor as a social ethics question; it is a gospel question." (Bosch, 2011:446). Poverty and marginalisation therefore lay bare "the indissoluble connection between theology and social ethics." As explained above, the city of Accra is currently home to a large number of residents belonging to the category of the deprived and underprivileged, and Christian ministry and other faith-based interventions in general have the onerous responsibility to create an enabling environment that offers such persons the opportunity for a transformed, renewed and flourishing life.

\section{Research Approach}

The research adopted a qualitative approach involving literature study, interviews and discussions in order to obtain enough understanding of the most pressing issues in the city of Accra. The multi-disciplinary and multi-perspective approach included phenomenological, missiological and environmental impact study. Primary and secondary sources were accessed through library research and digital

6 UN Universal Declaration of Human Rights, 1948 Articles 1,2,3. 
documents as well as information from the news media. The objective was to create awareness for civil advocacy, Christian social intervention and environmental renewal, and also receive inputs to help infuse such matters in the curriculum of theological institutions. Focus group discussions as well as one-on-one interviews helped to gather relevant information for analysis. A purposive sampling technique was adopted in which the researcher identified the specific and appropriate issues to be tackled and the persons to be interviewed. Inputs were also received from city authorities, civil society activists, leaders of faith-based organisations, religious and theological educators as well a five-member advisory team that accompanied the research.

Three focus group discussions and interviews greatly enhanced information and knowledge related to the research and expanded the discussion in many different ways. The participants in the discussions were all connected to theological education in one way or another and therefore, the main question for all three groups was:

Considering that Ghana (Accra) is currently experiencing rapid urbanisation which has resulted, among other things, in various fractures in daily living, how should your institution re-organise its curriculum and training programmes to respond to this phenomenon?

Other secondary questions were specific to each group.

The first group was made up of six colleagues of the teaching faculties of two theological institutions, comprising two Bible scholars, a scholar in philosophy, ethics and environmental issues, a church historian who is also a mission and evangelism scholar and two scholars in the study of religion. All six have been theological educators for considerable periods of time and have lived and operated in urban centres for years. The second focus group comprised three $\mathrm{PhD}$ students investigating different aspects of urban Christian mission in Accra for their dissertations. For this group the main question was varied to solicit views arising from their on-going research.

A third focus group was made up of four graduates from different theological institutions in Accra who have been working on the field for at least three years. Their views were solicited to assess their current performances on the field in the light of the theological education and preparation for ministry they received in their different institutions. They were requested to assess their training and preparation for ministry by choosing between (a) quite empowering (b) reasonably adequate (c) belpful but inadequate and (d) quite inadequate.

Finally, two city administrators of Accra (a member of the Metropolitan Assembly and a projects coordinator of a Municipal Assembly) were also interviewed 
to understand their views regarding the current state of Accra and the chances of collaboration with theological educators and faith-based organisations in general to address pressing challenges of the city.

This study is expected to significantly impact the curriculum design, pedagogy and methodology in theological institutions in Ghana and consequently, Christian ministry delivery in Accra and other cities with similar challenges. It is also envisaged to contribute to building graduate scholars who will be motivated to study firsthand the state of their urban communities and demonstrate solidarity with them. In addition, opportunity is provided for the development of relevant courses that offer opportunity to reflect on the changing nature of the urban environment.

\section{Findings of the Research}

The major findings of the research give an indication of the main issues that have been unearthed and proposals for responding to them, especially relating to theological education and its potential input into addressing the indicated challenges.

\subsection{The State of Theological Education in Accra}

Our preliminary findings were related to the number of theological institutions operating in the city of Accra, their current state, mode of operation and nature of the curriculum. The aim was to learn about their objectives and major aspirations and be able to determine whether these institutions are conscious of the urban environment in which they operate, and the extent of their awareness and the efforts, if any, towards attaining or maintaining a flourishing city. To begin with, we needed to be clear about the criteria for designating an institution as a theological educational facility. Having obtained a list of all institutions whose names and other characteristics suggested that they might be involved in some form of training with a theological bias, it eventually became necessary to separate them into three camps as follows:

1. University/Seminary referring to academic and vocational training institutions with a systematic concentration on academic theological studies.

2. Bible School referring to institutions with emphasis on imparting Bible knowledge for the benefit of church leaders, workers and church members generally, with little emphasis on theology as an academic discipline.

3. Leadership Training Institution referring to institutions offering Bible-based knowledge to produce Christian leaders for both church and society.

In all, seventeen tertiary institutions were identified in Accra, with varying levels of concentration in theological education: ten (10) in the University/Seminary category, four (4) in the Bible School category and three (3) in the Christian Leadership category. 


\subsection{Evidence of Urban Consciousness in Theological Education}

Only four of the institutions surveyed may be described as consciously and deliberately isolating urban orientation and praxis as important components of their programmes. Of these, the Trinity Theological Seminary at Legon has the best developed urban ministry programme which has been running since 2010. The Seminary currently offers a course in Urban Mission at the Master of Theology (MTh) level and about eighty-six students have gone through this course so far. A certificate course in Transformational Urban Leadership (CTUL), which ran for some time, has been temporarily suspended pending re-organisation and increased publicity. A Master of Arts (MA) programme with specialisation in Urban Mission and Ministry is also on the drawing board awaiting accreditation.

The University of Ghana (Department for the Study of Religions) in Legon normally has its major concentration in the study of religions generally. Recently, however, the department has been paying attention to urban issues and their impact on religion. In 2018, the department organised a highly successful International Conference on the theme: Religion and the 21st Century City: Openings and Closures. ${ }^{8}$ The department intends to sustain the great interest which this conference evoked in the coming years. The Faculty of Theology and Mission of the Pentecost University College at Sowutuom has no emphasis on urban studies, yet in studying the courses on offer in the Bachelor of Theology programme, we came across an aspect of a course that refers to urban church planting. The reading list for that course also includes one book on Urban Ministry9 which may be an indication that awareness of the urban phenomenon is not altogether lost in this institution. A similar statement may also be made about the Valley View University located at Oyibi. At an International Conference on: The Bible, Cultural Identity and Missions organised in April 2014, the conference papers included topics on "Current trends in urban mission" which touched on aspects of urban realities in Africa. ${ }^{10}$ However, current programmes and courses at the university give no indication of a desire to follow up on this. It is therefore clear from our study that with the exception of the Trinity Theological Seminary, the other afore-mentioned institutions may not be said to be putting adequate efforts in responding to the ongoing urbanisation of Accra.

7 The MA programme is designed as a postgraduate study that offers specialisation in urban mission studies whilst the MTh offers only one course in urban mission together with other required courses. Both offerings engage the city generically with specific communities offering opportunities for field study.

8 The conference which took place in June 2018, was attended by participants from over twenty countries.

9 The recommended book was Harvie Conn \& Manuel Ortiz 2001. The Kingdom, the City and the People of God. Illinois: IVP.

${ }^{10}$ Speakers at this conference were drawn from various tertiary educational institutions across Ghana. This researcher was a keynote speaker at this conference. 


\subsection{Lack of Clear Urban Orientation or Engagement}

The five other institutions in the first category, have no explicitly stated efforts in responding to the ongoing urbanisation in Accra. ${ }^{11}$ The same goes for the four institutions in the Bible School category ${ }^{12}$ as well as those in the third category (Christian Leadership) ${ }^{13}$ Our conclusion therefore is that the greater number of theological institutions in the city of Accra are yet to develop an adequate awareness of the impact of urbanisation on the city and the need for a sustained response.

The research also reveals an enormous lack of awareness of the impact of urbanisation among various categories of society including educators in theological institutions as well as products of these institutions. In chats with a number of Christian leaders engaged in ministry in urban areas, almost all of them indicated a glaring disconnect between their training and the practical situation on the ground. Again, in spite of the obvious association between urbanisation and some forms of social deprivation, like homelessness, this research has revealed that very few of Accra's theological institutions considered theological education and curriculum interventions as important predictors in dealing with the phenomenon.

\section{$\mathbf{5 . 3}$ d. Independent Views from Participants}

In this section, we summarise the main views expressed during interactions, with comments where necessary. One clear discovery was that although some institutions appeared to have little or no orientation or concern for the consequences of urbanisation, quite a number of individuals associated with these institutions did have independent views worth taking note of. When asked whether they considered themselves adequately informed and oriented regarding the urbanised environment in which they were operating, six faculty colleagues unanimously confessed not having adequate knowledge and orientation of the phenomenon. Two of them however added that they often brought the urbanising trends in Ghana into focus in their teaching and mentoring of students, by getting them to investigate how the Bible may respond to some of the tough realities of rapid urbanisation. Another colleague proposed the promotion of practical ethnographic studies of urban communities

${ }^{11}$ These other institutions are: Central University - School of Theology \& Mission (Accra), Regent University of Science and Technology - School of Theology (Accra), Ghana Christian University College (Dodowa Road), St Paul's Catholic Seminary (Sowutuom), Heritage Christian College (Amasaman) and Good News Theological Seminary (Oyibi).

12 These are: Dominion Theological Seminary (Spintex), Mount Sinai College of Theology (Accra - with main campus in London, UK.), Anagkazo Bible Seminary - LCl (Korle Gonno), School of Restoration (Royal House Chapel International), Accra.

${ }^{13}$ These are: Christian Leadership College (Haatso), Global Theological Seminary (Adentan), Glory College of Theology and Leadership (Sakumono). 
such as slums. There was also general agreement on the need to imbibe an urban consciousness which must reflect in the curricula of their institutions.

The second focus group comprising three PhD students suggested that TTS and other institutions must be encouraged to practice inter-disciplinary teaching and learning in response to the many-faceted urban phenomenon. ${ }^{14}$ Institutions may also consider bringing selected inhabitants of the city to the classroom for interaction with students and also offer all ministerial students the experience of immersion in the city, and writing a related paper before graduation. Overall, this group called for a complete restructuring and re-orientation of the curriculum for theological institutions in Ghana.

A third focus group comprising graduates from different theological institutions in Accra who have been working on the field for at least three years, were requested to assess their training and preparation for ministry. All were of the opinion that the little orientation they received was quite helpful but grossly inadequate. There was unanimous expression of a general helplessness in relating with leaders of other faith-based organisations in the city and in dealing with social challenges like homelessness. The following specific deficits were identified in the training programmes of their different institutions: first, a general handicap in dealing with counselling issues especially pertaining to marital challenges of urban people as well as gay/lesbian issues. Secondly, two respondents explained how they needed to first get used to the urban environment before trying to help others with their challenges. On the issue of curriculum interventions, there was general agreement on the need to extend theological education and formation beyond the campuses of theological institutions and develop positive relationships with various stakeholders including city administrators.

\section{Imagining African Values and Spiritualities for Meaningful Impact}

Christian imagination is often a reference to the theological sense of enacting change by the healing of brokenness, segregation and social decay. William Jennings has pointed out that there is "within Christianity a breathtakingly powerful way to imagine and enact the social, to imagine and enact connection and belonging." (Jennings, 2011:4). He also emphasises Christianity's "imaginative capacity to define the social, to claim, to embrace, to join, to desire ..." (Jennings, 2011:6). Unfortunately, the Church appears to be suffering from a "diseased social imagination" which has resulted in the Church practising a faith devoid of love and concern

14 Inter-disciplinary teaching refers, in this instance, to a practice where teachers of different disciplines take turns to handle a topic from their varied perspectives in order to expose the student to as many views and dimensions as possible. 
for the ordinary person in society. Imagination was sometimes what energised the prophets of the Old Testament into action as God gave them 'a peep into the future' that emboldened them to pursue a certain course of action. There is no doubt that this neglected innate Christian quality can contribute to the wellbeing of the city of Accra if rekindled and appropriately applied. In the next sections, we employ the Christian imagination to address various issues of urbanisation unearthed in this research.

Most contemporary theologians generally acknowledge that theology is most meaningful and useful when done in context. Different contexts of cultures and languages therefore become vehicles that no serious theologian can ever ignore in the quest to communicate truth. A normative, one-size-fits-all theology has long been rejected in any serious-minded academic discourse. It is therefore insightful that the inaugural meeting of the All Africa Conference of Churches in 1963 encouraged African churches to chart a new course in theological education, warning that the current system was at variance with the context of most African Christians. Many years later, the same call kept recurring in various meetings of African Christian leaders, emphasising that the crisis facing African Christianity was essentially theological (Moyo, 1990:33). Contemporary scholarship has continued to chart this course with increasing contextual models that seek local relevance for local discourse. Effective theological formation in Africa must therefore be founded on sound context-sensitive education, and the continent's cultural resources must be employed to evolve curricula relevant to its context. In other words, it is only a contextual theology which emphasises the African environment and worldview that can be trusted to meaningfully and effectively connect the city and the seminary/theological academy. In this vein, we now proceed to discuss some specific African (Ghanaian) resources that might be considered in the quest for relevance and flourishing in the African urban context and the city of Accra in particular. The indigenous Ga culture of Accra abounds in many life-affirming values and other socio-political capital which can be infused into the training programmes of theological institutions to produce positive impact and influence justice-seeking practices in the city. These values still retain an innate potency even if they lack easy acceptability and application because they are in competition with many different others. We are also aware of the danger of generalisation and over simplification as though African values are good just by being African.

\subsection{Reinventing the Ga Spiritual Landscape and Extended Family}

The Christ event and its antecedent reference to the Exodus is crucial for all Christian approaches to any form of social intervention since it is a story of redemption from oppression in the broadest sense of the word. It embodies the very 
concept of life and, in this case, it is God's specific action to give life to his people. Philip Laryea has pointed out that the concept of wala (life) among the Ga has various dimensions which include communal, relational and redemptive considerations. "Wala for Ga people includes anything that enhances life: good rainfall, bumper harvest, good health, and vitality in procreation in both humans and animals." (Laryea, 2011:129). He further explains the philosophical undertones of the traditional wishes used to usher in the traditional New Year, the central theme of which is wala and the overarching desire to escape "a visit of the black cat."15 "Wala for the Ga begins on the eighth day" and every Ga child who survives this day is accorded social status and recognition as a member of the human society, and is expected to live long and contribute to society's wellbeing (Laryea, 2011:129130). The Ga therefore conceive of wala in relation to others in community: "it is the quintessence of society and neighbourliness" (Laryea, 2011:130). If therefore, communality, neighbourliness and human wholeness are no longer cherished ingredients in daily life, as is the case in Accra today, the traditional perception of life may come in handy in evolving new attitudes to life in community with others. Christian theology affirms the essence of Jesus' mission as an offer of wala in all its fullness (John 10:10), a theme that theological education today is obliged to continually emphasise as the quintessence of a global city like Accra.

Related to the foregoing is the Ghanaian spirit which attaches great importance to the concept of the extended family where the well-being of the whole community is pursued by all because it is within the collective whole that the individual finds his/her being. The greatest premium is placed on good relations with other members of the community as part of social culture and no individual may be allowed to be a world unto him/herself. In contrast to the Western world where daily life is spent mostly indoors, Africans live most part of their lives outside and in the full glare of others. Communal living therefore requires that one interacts with and shares life with others all the time. In the past, this form of communality generated enormous attachment not only to immediate and extended family members, but also to others in one's immediate environment. The Ga extended family is a tree with many branches and no branch has any life of its own unless it remains part of the big tree. If there are any orphans or displaced persons in the community, they are the responsibility of all, and when they get taken care of, no one person may claim the credit or praise. Growing urbanisation has unfortunately introduced much cultural, ethnic and linguistic discord that has greatly eroded the value of this cherished heritage and transformed the city of Accra into a fractured conglomeration of self-serving individuals rather than community-conscious inhabitants. Most

${ }^{15}$ The black cat is a symbol of evil among the Ga of Ghana 
migrants in Accra may already have experienced communal living prior to settling in Accra and may therefore be positively inclined to a reinvention of such social cohesion in the city. Theological education, combined with the African preference for pluralism, as exemplified in the traditional extended family system, can contribute to this exercise by developing appropriate curriculum that usefully integrates this African value into their training programmes.

\subsection{Reinventing Hospitality}

Closely related to the concept of communal living is that of hospitality, without which the extended family system would collapse. The elders of the Ga people, in times past, cherished the saying, 'Ablekuma abakuma $w$ ' which haboured an implied meaning of openness to foreigners who had migrated to Accra. The term, ablekuma, originally referred to the minor corn harvest in October/November which was considered an extra blessing that ensured the availability of the staple grain into the next planting season (March/April). This saying therefore evolved into an expressed wish that all who would otherwise feel lost or unsure of sustenance, to expect a welcome once they stepped on to Ga land (Accra).$^{16}$ Today, this is no longer a popular or attractive expression among the Ga people owing to the ever-escalating incidences of forfeiture of their lands to foreigners who have moved into the city. It has indeed become a nightmare for many young indigenes of Accra whose lands have either been acquired by government or sold by their family heads to non-indigenes. ${ }^{17}$ The growing tension and frustration occasioned by this state of affairs can be an incentive to evolve and promote new theologies that can revive the ancient spirit of ablekuma welcome for the stranger such as will not disadvantage the indigenous Ga people and yet be fair to the migrant.

\subsection{Governance}

Accra has had a long history of association with European colonisers, a relationship that started as trading partnerships of equals, but soon turned into domination

${ }^{16}$ Some traditional elders of Accra have explained that this saying depicted more than just a general welcome for foreigners. This tradition claims that the ablekuma expression originated from a period in the settlement history when the Ga people were eager to forge alliances with others ethnic groups in order to develop a formidable army to ward off enemy attacks. This therefore produced not just tolerance but indeed an extra welcome for migrants and other strangers, in particular, young and ablebodied men.

17 Ga family lands are, by tradition, vested in the heads of clans (patrilineal elders) who often dispose of family lands without proper consultation with and accountability to family members. The result is that many of the present generation of young indigenous Ga folk have been alienated from their own ancestral landed property. For this reason, land litigation is indeed one of the commonest cases handled by the law courts in Accra. 
by the latter owing to the concept of governance that grew out of the relationship. "Government" (Amralo) came to be seen as an alien ruler far removed from the people and operating through orders and instructions issued from beyond the sea. Although citizens were compelled to pay taxes in order to receive service from government, they were largely prevented from participating in governance. Even Ghanaians who were employed by Government were seen largely as part of the European 'establishment' whilst continuing to be part of the traditional society. This colonial mentality gravely affected the understanding of governance among the Ga people who were used to being governed by majiats $m i$ (literally, owners of the towns) and whose roles had been usurped by the colonising powers. This mentality has resisted eradication even into modern times and is partly responsible for the continuing difficulty of succeeding governments to inculcate a sense of civic responsibility in the urban population.

Margaret Field, a British anthropologist who undertook extensive studies of the Ga people in the 1930s and 1940s, attempted to explain the ambivalence in the attitude of the indigenous $\mathrm{Ga}$ in their relations with the British colonial rulers. In her view, British colonial officers were regarded with both admiration and disdain owing to certain actions and attitudes in their dealings with the local people. They were known to disrespect traditional sacred places, wilfully destroying them without performing necessary rituals. Government was therefore generally regarded as a ruthless, immoral ruler with enormous powers to enforce unjust laws (Field, 1937:131) At the same time, the indigenous Ga also credited the colonial rulers with benevolence in the provision of water in times of drought (through pipes) and medicine and vaccination during epidemics. It was difficult to build genuine trust in such circumstances and many Accra dwellers grew accustomed to seeing government as an institution to be exploited for what it could offer, but to be resisted for its oppressive policies. Government and the governed therefore developed into two polar ends of daily living and have remained largely so even today. This lovehate encounter was never resolved even when indigenous people took over the governance of Accra since the new rulers were perceived as simply stepping into the shoes of the departing colonisers and continuing to operate the same obnoxious system. The distortion in attitude to 'government' by inhabitants of Accra must be of particular concern for theological institutions operating in the city, considering that more than half of the city's inhabitants belong to one church or another (GSS, 2010 Table 4.17) and whose pastors are products of theological institutions. It certainly makes sense to consider ways in which theological education might take up and help infuse the all-important quality of civic responsibility through the curriculum. In doing this, one could make a strong case for the use of the mother tongue in theological discourse since much interaction in the churches of Accra is 
done in the local languages. Theological discourse in Ghana has, for too long, been presented and consumed in the English language which has failed to connect the Christian Gospel with ordinary daily life.

\subsection{Social Protection and Nurture}

Homelessness was an unknown concept before Accra became an urban centre, and in the rare cases in which it existed, homelessness was always a temporary condition with every hope of amelioration in the shortest possible time. Therefore, every stranger was only temporarily homeless and was likely to be offered a place to stay for even that temporary period. Homeless children, in particular, are a blight on the conscience of any society, and the presence of children on the streets of Accra today is a clear pointer to a broken and insensitive society. A society that shirks its responsibility for the care and nurture of its young ones is surely heading for a future of brokenness. The Ga people of Accra cherish the saying that "it is one person that gives birth to a child, but it takes the whole community to bring him/her up." 18 The value of corporate responsibility for the upbringing of the next generation is one that must attract the attention of theological education, which currently makes no space for advocacy for the rights of the child. Such advocacy has for too long been left in the hands of civil society organisations which often neglect the religious and theological dimensions of the phenomenon.

\section{Recommendations}

In addition to the many concepts, themes and suggestions that have emerged from this research, we conclude with a few more general recommendations for the consideration of all stakeholders identified in the research. The place and role of theology in public discourse has, in recent times, been given much space in scholarly discussions and we endorse Emmanuel Katongole's caution that Christian theologians must desist from the tendency to allow their contributions to be "shaped and defined by the secular disciplines ..." (Katongole, 2005:137). The city, being a shared human space, must be allowed to benefit from all legitimate offerings, theology being as important as any other.

We begin with the Trinity Theological Seminary (TTS), currently the leading theological institution that displays awareness, enthusiasm and some commitment to the quest for engagement with the urban sphere. TTS must therefore take a leading role in bringing about transformation in this regard. TTS must take the initiative to convince a number of other theological institutions in Accra to focus on urban

18 The Ga expression: Mokome $f$, shi jeee mokome I , testifies to the imposed communal responsibility for the care of children (especially the homeless) in Ga society. 
studies from certificate to doctoral and postdoctoral levels in order to develop a pool of practitioners and experts for the benefit of the city generally. In collaboration with other stakeholders, the establishment of a Centre for Urban Studies (CUS) may be envisaged with various specialisations including theology and intercultural studies. This is an initiative that must also necessarily include city administrators and non-governmental organisations.

Furthermore, TTS is being urged to propose and collaborate with the Accra Metropolitan Authority (AMA) to start planning the 150th anniversary celebration of the establishment of Accra as the capital city of Ghana which falls in the year 2027 with one of the objectives being the development and implementation of a comprehensive policy to attain a prosperous, eco-friendly and flourishing city. This project (Accra 2027) can become a forum for resurrecting various failed or suspended urban renewal initiatives of Government. ${ }^{19} \mathrm{Of}$ particular interest for this study, is the Inner City and Zongo Development Ministry established in 2017 to bring renewal to inner city and zongo communities where much squalor and deprivation prevails. ${ }^{20}$ Similarly, the Accratopia concept must receive a boost during this celebration. ${ }^{21}$ In the process, we can envisage churches in the city being transformed into community action centres where socio-economic and political issues receive adequate attention and relevant interventions are initiated. In addition, TTS needs to urgently institute a forum for periodic colloquia for the study of urban theology and ministry that will result in relevant publications for both the academy and Christian ministry in general. It has also become imperative that a deliberate effort is made to develop the city environment as one of the classrooms for theological education where city administrators and city pastors are partners in teaching and learning. Theological institutions, therefore, need to design short, intensive and participatory courses, besides the normal curricula, to meet the needs of all involved in Christian ministry in an urban context.

\section{Bibliography}

19 These include the National Urban Policy adopted in 2012 which also included an Action Plan, and the National Housing Policy of 2015.

${ }^{20}$ Zongo communities are outlying informal settlements originally situated on the outskirts of the city which have now become very much incorporated into the city due to expansion, but lacking basic amenities like water, sanitation and proper housing. They are similar to the favelas of Latin American cities.

${ }^{21}$ Accratopia is a concept that tries to promote a utopian vision for the city of Accra towards the year 2050 to transform the city into a livable and preferred location in Ghana. For now, Accratopia remains an undeveloped wishful concept awaiting content and expression. A theological response and content, when developed, will surely contribute much to its eventual implementation. 
Bosch, D.J. 2011. Transforming mission: Paradigm shifts in theology of mission. 20th Anniversary Edition. Maryknoll, N.Y: Orbis Books.

Central Bureau of Statistics. 1973. 1970 Population census of Ghana. Special Report D.

Accra: Ghana Census Office.

Collins, J. 2004. Transactions of the Historical Society of Ghana. New Series, No. 8, 208-226.

Dickson, K.B. 1970. Urbanisation in precolonial Ghana. Accra: Annual Museum Lectures 1969, 1970.

Fage, J.D. 1969. A history of West Africa - An introductory survey. Cambridge: Cambridge University Press.

Field, M.J. 1937. Religion and medicine of the Ga People. London: Oxford University Press.Ghana Statistical Service 2010. Population and housing census, summary report of final results. Accra: Ghana Statistical Service.

Ghana Statistical Service. 2011. Population and housing census, 2010: National analytical report. Accra: Ghana Statistical Service.

Ghana Statistical Service. 2013. 2010 population and housing census: National analytical report. Accra: Ghana Statistical Service.

Ghana Statistical Service. 2014. Urbanisation. Accra: Ghana Statistical Service

Ghana Statistical Service. 2019. Population projections \& prospects. Accra: Ghana Statistical Service.

Grant R., \& Yankson, P. 2002. City profile: Accra: Cities 20(1), 65-74.

Jennings, William 2011. The Christian Imagination: Theology and the Origins of Race, New

Haven: Yale University Press.

Katongole, E. 2005. Hauerwasian hooks and the Christian social imagination. In God, truthand witness: Essays in conversation with Stanley Hauerwas, ed. L Gregory Jones, Reinhard

Hutter., \& C.R Velloso Ewell. Grand Rapids: Brazos Press.

Laryea, P. 2011. Yesu, $h$ m $w$ nunts, akropong-akuapem: Regnum Africa.

Moyo, A.M. 1990. Theological education for ministerial formation and the Church in an African context. In J.S. Pobee and J.N. Kudadjie. Theological education in Africa: Quo Vadimus? Accra: Asempa Publishers.

Obeng-Odoom, F. 2011. The informal sector in Ghana under siege. Journal of Developing Studies, 27(3-4), 355-392.

Quarcopome, S.S. 1992 Urbanisation, land alienation and politics in Accra. ResearchReviews, New Series 8,(1-2).

Songsore, J. 2009. The urban transition in Ghana: Urbanisation, National Development and Poverty Reduction. London: IIED-UNFPA.

UN-HABITAT. 2011. Ghana housing profile. Nairobi: United Nations Human Settlements Programme.

United Nations. 1948. Universal declaration of human rights. 